\title{
IMPROVING WORK ORGANISATION IN THE PRODUCTION HALL - A CASE STUDY
}

\author{
Michał ZASADZIEŃ \\ Silesian University of Technology, Faculty of Organization and Management; michal.zasadzien@polsl.pl, \\ ORCID: 0000-0002-3181-9815
}

Purpose: The aim of the research was to assess the effectiveness of implementing Lean Manufacturing (One-Piece-Flow) elements in a company producing shock absorbers.

Design/methodology/approach: With the help of VSM, the most important problem in the production process was diagnosed, and by using the 5 Whys tool, the root causes of the problems were identified. A simulation of introducing the One-Piece-Flow system into the production line was then used to estimate the most optimal solution. After choosing the solution, it was implemented, and the results obtained were verified.

Findings: As a result of the conducted analyses, the most important problems related to planning, scheduling and the flow of intermediates were identified. The 5 Whys analysis allowed for the grouping of individual problems by common causes. Detailed solutions to the problems were proposed, which were included in the future Value Stream Map.

Research limitations/implications: Conducting research in a working production process is limited and faces significant resistance from managers.

Practical implications: The most important effects of implementing an improvement plan were minimising inventory from 138,062 units to 25,000 units, which reduced costs and indicates reduced waste. Lead time was limited to 9.67 days from 56.96 days.

Originality/value: Research results confirm the effectiveness of introducing only some solutions of the Lean philosophy. This is particularly important if the enterprise is unable to comprehensively implement the Lean Manufacturing concept due to organisational or financial reasons.

Keywords: VSM, logistics, process, one-piece-flow, stock, 5 whys, lean.

Category of the paper: case study.

\section{Introduction}

The basis of business activity in every production enterprise is production, as a result of which utility values are created. Production is defined as the adaptation and transformation of work objects into a product by means of labour (Fertsch et al., 2010). Therefore, an enterprise 
can be treated as a production system, constituting an energy, material and IT system that is intentionally designed and organised and used by people (Szymonik, 2012; Habek, 2013). The main elements of the product manufacturing system are production processes. Next to them, in full symbiosis, there are side and auxiliary processes, such as:

- production preparation process,

- procurement process,

- selling process,

- distribution and customer service process (Matuszek, 2012).

The production system is expected to manufacture products that meet customer requirements and are competitively priced in the shortest possible time. The ever-growing customer expectations regarding price, time and product properties and the need to ensure ever greater production flexibility results in the need to improve all processes in manufacturing enterprises. Among the processes that need improvement due to production costs and efficiency, an important position is occupied by processes related to planning, flow of raw materials and semi-finished products and their storage, including maintaining correct levels of inventories (Dyczkowska, 2012).

The implementation of improvement actions must be carried out with a thorough analysis of the current state and, at a later stage, finding the root causes of problems. Meticulous carrying out of the initial stage of work guarantees the development of effective improvement actions. Modern process engineers have at their disposal a whole range of methods and tools to support their activities, starting from the management concepts of Lean, Six Sigma or TQM and ending with simple tools. Among the many concepts, methods and tools, the Lean concept stands out with its philosophy of combating waste.

\section{Lean Manufacturing in production logistics}

Lean Thinking is a management philosophy whose genealogy is strongly associated with the Japanese company Toyota (Jóźwiakowski, 2015). The origin of the Lean concept dates back to the 1950s, when Toyota introduced the well-known Toyota Production System. However, the term "Lean" was firstly used in 1988 by John Krafcik (Pawłowski et al., 2010), and it was popularised by (Womack et al., 1990) from MIT. The word "lean" means adaptation and slimness in relation to the human figure. In the case of management systems, the term "lean" means a "slimming" of the system in terms of rules of conduct and consumption of material resources, stocks of finished products and work in progress and the space used in production halls (Wolniak 2013; Cholewicka-Goździk, 2001; Czerska, 2012; Hobbs, 2003). According to the concept of Lean Thinking, the primary goal is to "produce more with less resources" (Womack, and Jones, 1996). Based on this assumption, five main principles were formulated: 
1. Value. The starting point for applying Lean Thinking is the correct definition of the perception of value from the customer's point of view. Focusing on the entire enterprise, the main features of the product and associated benefits for which the customer is willing to pay should be identified (Womack \& Jones, 1996; Picchi \& Granja, 2004).

2. Value stream. This covers all actions taken to move the product through the entire production process, from the purchase of raw materials and materials to the delivery of the finished product. The analysis of this path is crucial from the point of view of optimiszing the costs of flows throughout the entire supply chain, and its analysis is crucial from the point of view of improving efficiency in the enterprise (Czerska, 2014).

3. Flow. The concept of flow is one of the basic elements of the Lean Thinking philosophy for the complete removal of waste. It is related to the idea of materials and information flowing without interruptions, thus eliminating waste and reducing the time to generate new products or services (Womack \& Jones, 1996). Continuous material flow means transferring the part to be processed, from one process to the next, as soon as the operation on the part is completed (Rother \& Shook, 2003).

4. Pull. The pull principle assumes the production of products in the amount that is needed and only when they are necessary, i.e. Just in Time. This means that as long as there is no feedback on the need to produce a finished product, production of these products should not be started (Jóźwiakowski, 2015; Tommelein \& Weissenberger, 1999).

5. Perfection. Lean Thinking focuses on continuous learning and improvement (Lean Enterprise Institute, 2003; Fujimoto, 1999). Process improvement can be based on two methods - by continuous improvement through many small changes in individual operations (the so-called Kaizen method) or by introducing revolutionary changes in entire processes (Jóźwiakowski, 2015).

When deciding to implement Lean principles in an enterprise, managers have a number of methods and tools at their disposal to support their activities. The most important include (Pawłowski et al., 2010; Jóźwiakowski, 2015; Wolniak, 2013):

1. VSM. Value stream mapping is a tool that analyses flows of the material and information necessary to deliver a product to the customer. The advantage of using this method is the ability to "observe" both the process and the flow of communication within the process or value stream (Nash \& Poling, 2008; Muniyappa \& Prasad, 2014).

2. Kaizen. Continuous introduction of small changes and improvements resulting from the constant analysis of individual operations and procedures, constituting the support of the selected sphere of the company's activity (Gulati, 2009; Łazicki, 2011; Masaaki, 2007; Szymańska-Brałkowska, 2010).

3. $5 \mathrm{~S}$. This is considered the basis for creating a work culture that allows one to quickly recognise and master elements of the work process using simple visual elements without using computers. The application of the $5 \mathrm{~S}$ methodology directly contributes to 
improving safety, reducing costs, improving quality and improving overall efficiency (Pawłowski et al., 2010; Wolniak, 2013).

4. TPM. Total Productive Maintenance. This is a resource management strategy that emphasises collaboration between production and maintenance departments. Its main purpose is to increase the efficiency of using technical means involved in the production process (Legutko, 2009).

5. Kanban. This is a tool supplementing and supporting the JiT system. The Kanban system has been designed to act as a precise traffic signal in real-time material flow management, sending clear signals when to start, slow down and stop production (Ordysiński, 2013; Czerska, 2014; Locher, 2008).

6. SMED. Single-Minute Exchange of Die means the possibility of retooling a machine involved in the production process within a single-digit number of minutes. The basis of this method is the assumption that long-term machine retooling on the production line reduces the efficiency of the production line and generates adverse phenomena, such as: increasing production series, limiting the range of products and increasing production inventory in progress (Kruczek \& Żebrucki, 2012; Szwedzka et al., 2014).

7. Poka Yoke. This method consists in eliminating the possibility of employees making mistakes, e.g. incorrect order of procedures or skipping one of them, incorrect assembly, mistake in the selection of materials, etc. The most common actions that can be used as part of Poka Yoke include: simplifying operations, using checklists, standards and measures (Stanek et al., 2011; Trojanowska et al., 2011; Hirano \& Shimbun 1989; Pascal \& Shook 2007).

Thanks to these and many other methods, it is possible to effectively and efficiently implement Lean principles throughout the enterprise, thus reducing waste, increasing productivity, quality and safety, as well as reducing operating costs.

The task of production logistics is to ensure the optimal flow of raw materials, materials, semi-finished products and purchased parts and information in the production process (Odlanicka-Poczobutt \& Kulińska, 2014; Szymonik, 2011). Depending on the scope of participation of individual subcontractors in the production process, the above-mentioned tasks can be implemented within a single enterprise, as well as between enterprises (Małkus \& Onderka, 2015). Therefore, production logistics should be treated as an element connecting supply logistics with distribution logistics (Michlowicz, 2011). Properly organised production logistics should therefore ensure (Topolski et al., 2015):

- full availability of raw materials and materials needed to complete an order,

- continuity and rhythm of production,

- adequate stocks of work in progress and finished goods,

- seeking to shorten production cycles,

- minimising deficiencies. 
Contemporary enterprises wanting to stay on the market decide to use a flexible organisation of production, which is characterised by a diversified production range, ability to respond quickly to changes in demand and flexibility of the production system (Pająk, 2006). The currently preferred short production series force companies to face additional difficulties related to material flow, production planning and scheduling. To effectively and efficiently respond to problems related to logistics processes, one needs efficient tools to improve these processes.

Today, improvement activities in the field of production logistics can be implemented using many methods and tools (Małkus \& Onderka, 2015). Quality management methods and the tools used in the Lean Manufacturing concept are some of these.

The basic tool of Lean Manufacturing, which identifies the causes of problems, wastes occurring and the reasons for too long time of completing customer orders, is Value Stream Mapping. The main advantage of this tool is the ability to analyse processes occurring in the enterprise from the moment of purchasing raw materials to the moment of goods delivery to the customer, taking into account all processes that occur simultaneously within the manufacturing process. Another advantage of Value Stream Mapping is the visualisation of the relationship between the flow of information and materials (Kolasiński \& Wiśniewski, 2016). Value Stream Mapping allows to one to visualise and collect information about:

- customer requirements and demands,

- form and time of information flow in the company,

- details of the manufacturing process and production inventory in progress,

- problems affecting the extension of the lead time,

- duration of the whole production process (Czerska, 2014).

Value Stream Mapping begins by identifying product families, in particular if we are dealing with a company that has a wide range. A product family is a group of products that are manufactured on the same machines, workstations and using the same processes and which consist of similar materials (Antosz et al., 2013).

The next three basic phases of this method are:

- PHASE 1. Diagnosis of the current state,

- PHASE 2. Creating a vision of the future state,

- PHASE 3. Creating an improvement plan.

The basis for developing a future state map and defining an action plan for implementing changes is the current state map, which is why this is the most important stage of the whole process (Michlowicz, 2012). An example map is shown in Figure 1. 


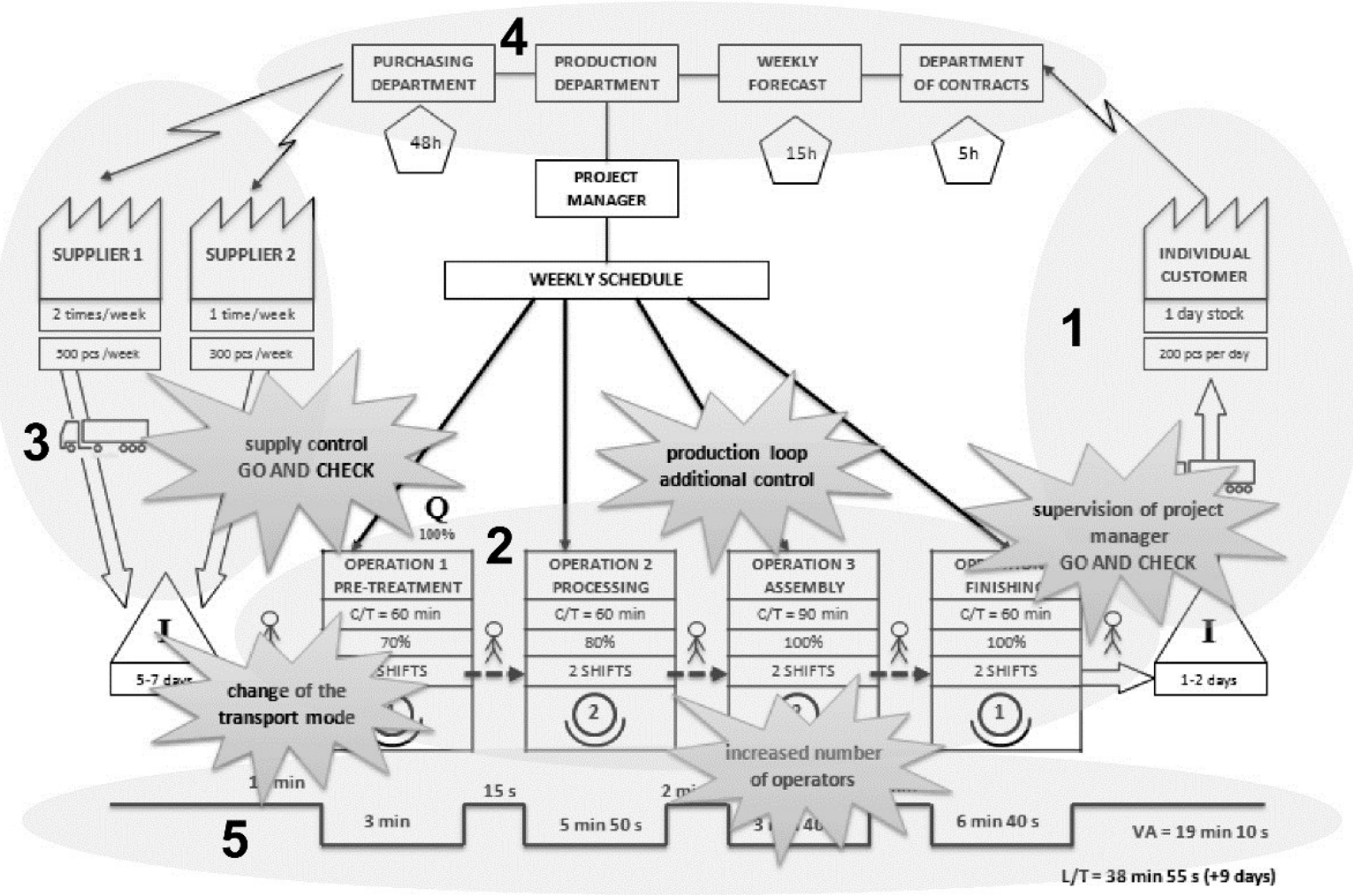

Figure 1. Current State Map with basic areas. On the basis of (Salunke \& Hebbar, 2014).

Area 1 presents the customer, his/her requirements, scope and method of communication.

Area 2 covers the manufacturing process, i.e. manufacturing operations, inspection, transport and storage. Each operation should contain:

a) For manufacturing operations:

- cycle time $(\mathrm{C} / \mathrm{T})$,

- retooling time $(\mathrm{C} / \mathrm{O})$,

- the number of pieces produced for one work cycle (pcs./C/T),

- lot size,

- number of positions,

- number of operators,

- defect level.

b) For transport operations:

- route length,

- transport duration.

c) For storage operations:

- inventory name,

- quantity in pcs or other measurement units,

- days of inventory on hand (DOH).

Area 3 is the supplier's characteristics. This area focuses only on the suppliers of key materials (strategic or valuable for the product). 
Area 4 illustrates the flow of information and indicates the relationship between physical flows, information flows and material flows in areas of processes such as planning, scheduling, inventory control, production reporting, placing orders and forwarding forecasts.

Area 5 is the timeline that fits at the bottom of the map. The timeline usually has $2 / 3$ levels; the top line means those times of the manufacturing process that do not add value, and the bottom line means those times of the manufacturing process that add value to the product.

We also see "clouds" on the map in Figure 1, which indicate the places of identified problems necessary for improvement.

\section{Research context}

The research was conducted in the Polish branch of a corporation dealing in the production of shock absorbers for the automotive industry. The company's suppliers are located on all continents, and the main recipients of the company's products are primarily companies located in Europe.

The research subject is the production process of a two-chamber, hydraulic, oil-gas shock absorber. The piston, which is mounted at the end of the piston rod, works in hydraulic oil in the compression chamber. When the shock absorbers work, hydraulic oil gets through the valves in the middle of the piston into the chamber between the compression chamber and the reserve chamber, and the valves control the oil flow, thanks to which the spring movement is slowed down. The gas used to fill the shock absorbers is nitrogen, thanks to which the oil does not foam. The reason for this phenomenon is oil aeration due to a sudden change in pressure in the chambers (Fig. 2).

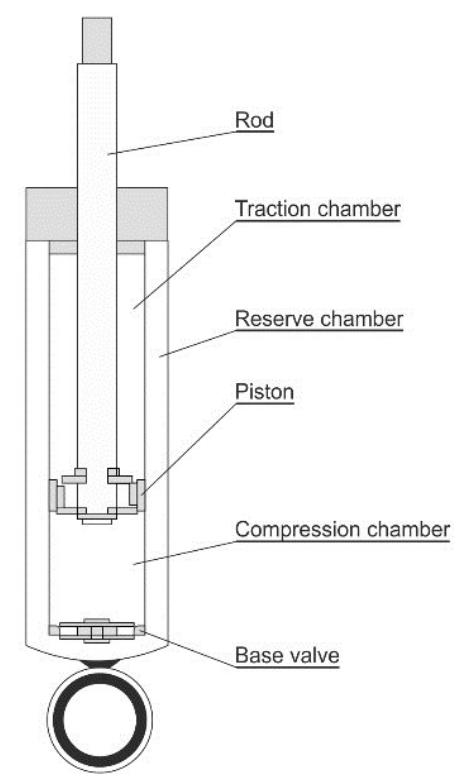

Figure 2. Construction of an oil and gas piston. On the basis of (Alonso \& Comas, 2006). 


\section{Production process}

The production of shock absorbers consists of operations whose map (including flows of semi-finished products through workstations) is presented in Figure 3.

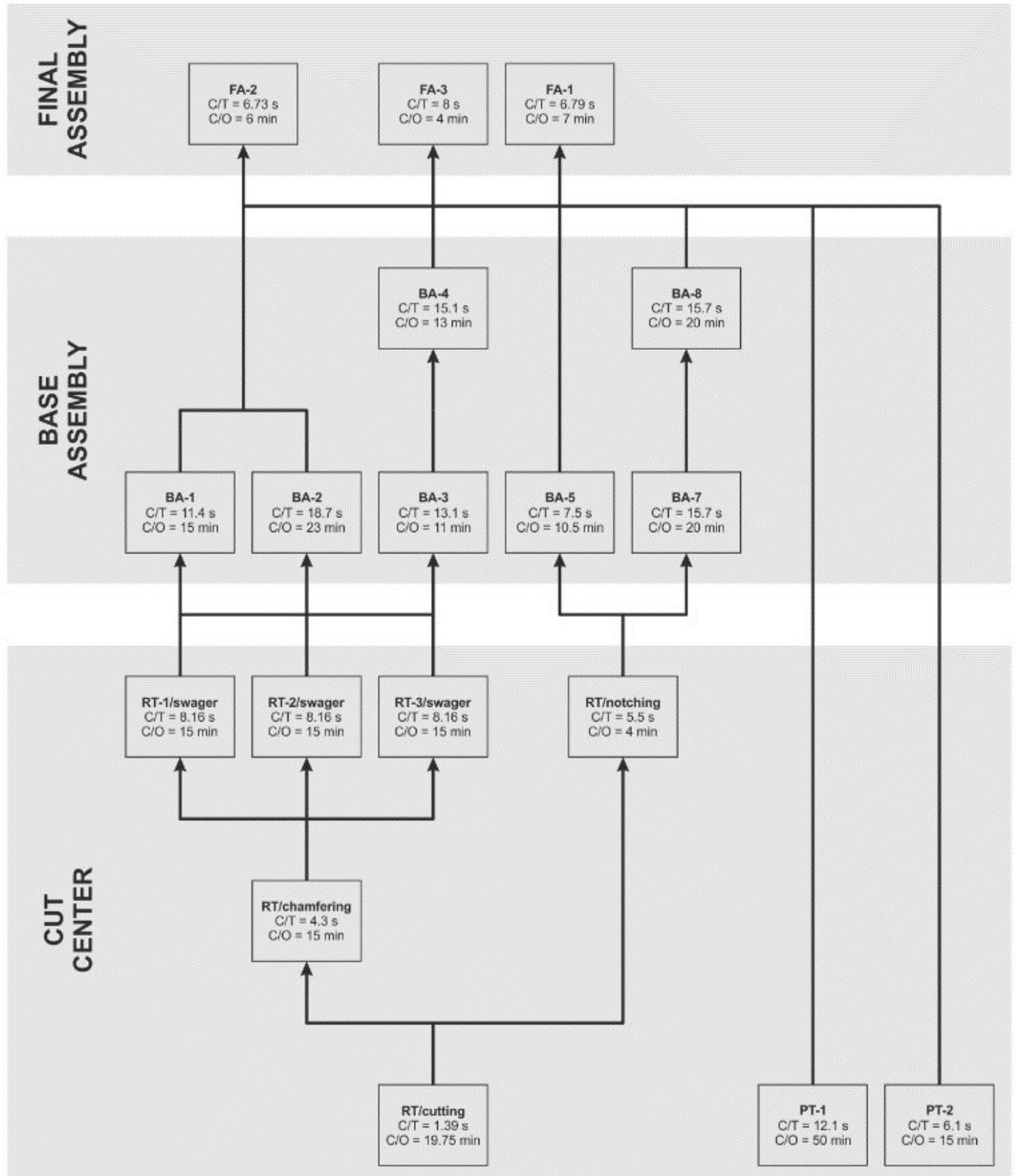

Figure 3. Positions and work centres. 
The first cells are in the cutting centre (RT - inner tube and PT - outer tube). The pipes supplied to the cutting centre are originally about $5 \mathrm{~m}$ long; the cutting machine then cuts them into smaller pieces of a length designed for each model of the shock absorber. The pipes then go to the station where the chamfering occurs. After this operation, the pipe is narrowed to the appropriate length (SWAGER). Another option, depending on the design, is the NOTCHING of the pipe after it is cut. Machined RT pipes go to BA sockets (BASE ASSEMBLY - producing basic shock absorber systems). External pipes are cut in the machine, which immediately finishes their ends by chamfering them. These pipes go directly to the FA centre. At the next station (BA-1/BA-2/BA-3), a metal bottom with a fixing handle is then pushed and welded to the pipe, and a metal element of a saucer shape is assembled. For this element, a notch was made at the cutting centre, on which the element sits. Hooks are also welded at these positions, which are used to route cables next to the shock absorber. At the next station (BA-4), the shock absorber mounting elements are welded. After such operations, we get an intermediate called the base assembly. In the final stage FA-2/FA-3 (FINAL ASSEMBLY), a PT pipe is then placed into base assembly with a piston mounted in it, which is ended with a valve and a piston rod. Automatic injection machines fill the shock absorbers with semi-synthetic oil. Two rotating electrodes then combine the piston system to the base assembly using a cover. The last operations are painting and packaging. All centres are divided into production lines producing rear shock absorbers (FA-1, BA-5/BA-7/BA-8) and front shock absorbers (FA-2, FA-3, BA1/BA-2/BA-3/BA-4). The RT and PT sockets, as well as painting and packaging (PAK-1, PAK2, PAK-3), are common for all lines (Charczyńska, 2018).

\section{Analysis of a production control and scheduling system using VSM}

Value Stream Mapping is a tool that was used to analyse the production planning, control and scheduling system. Thanks to this tool, all processes occurring in the company were presented in a graphic manner, and any errors that occurred in them were indicated.

The Lean concept divides activities performed in the enterprise into those that add value, those that do not add value but are necessary and those that do not add value and are unnecessary. In the enterprise, we also distinguish these activities.

Actions adding value: shock absorber production process.

Actions that do not add value, but are necessary:

- control after subsequent production stages,

- transport of materials in the warehouse and production hall,

- production of test pieces for process regulation. 
Actions that do not add value and are unnecessary:

- processing of incorrectly welded elements that were created in the production process,

- searching for ready semi-finished products on production buffers,

- searching for components in the warehouse that are not in the systemically designated location,

- production of defective products caused by employee error or a problem with the process/tool/machine,

- production not using the full production capacity of the stock of the machine tools.

Figure 4 presents the current state production process map, which shows the production of shock absorbers for one of the main customers. Transport of semi-finished products between production stations is carried out by an internal transport employee, and the components included in each of the semi-finished products are transferred to the stations by a warehouse employee. The standard volume delivered daily by the supplier is 10,000 piston rods, and the second supplier delivers twice a week, approx. 22,000 each time. Lead time (the sum of the time of purchase by the supplier of raw material, planning of production, execution of the product and delivery to the customer) is counted from the moment an order is received by the company to the moment of delivery of the component and ranges from 25 to 55 days. The company produces an average of 23,000 shock absorbers per day, and the main customer orders an average of 436,000 shock absorbers per month. 


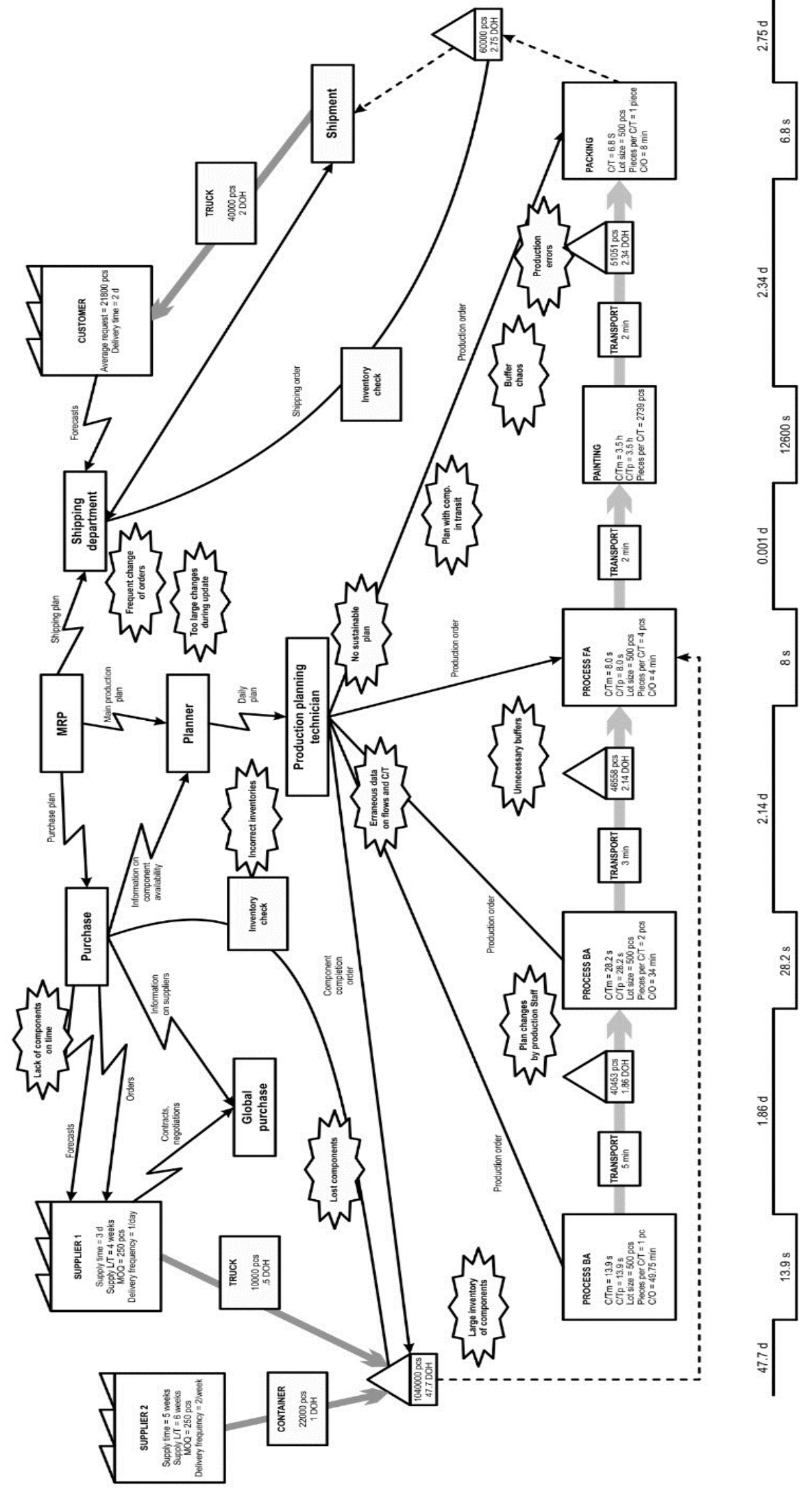

Figure 4. Current state map. 
The current state map presents problems that affect all processes in the company, but in particular, they negatively affect the planning process. These are:

- large inventory of components,

- no components on time,

- lost components,

- change of production plan by production staff,

- incorrect inventory,

- incorrect information on flows and $\mathrm{C} / \mathrm{T}$ (cycle time) for individual references,

- clutter at the buffer storage,

- unnecessary buffers,

- no sustainable plan,

- planning based on components in transit,

- too large changes during plan update,

- frequent changes of customer orders.

We also see the size of production buffers on the map: the total RT buffer is 35,549 items, the buffer for PT pipes is 40,453 items, the BA buffer is 46,558 items, and for FA, this is 51,051 items.

The current state map has shown that lead time related to all processes needed to perform one piece (production, transport, warehouse processes) amounted to 56.9598 days, and the production process itself only $12,656.88 \mathrm{sec}$. The most time added to lead time were from processes related to storage, which is why they should be the most focused on while creating an improvement plan.

To identify the causes of the problems presented on the process map (Fig. 4), the 5 Whys analysis was performed. The aim of the analysis is to learn the root causes of each problem and formulate suggestions for improvement. A synthetic view of the analysis performed is presented in Table 1.

Excessive inventory of components results from ordering unnecessary components. The erroneous demand for unnecessary components for production appearing in the IT system is caused by sudden changes in orders made by the customer. This is a significant problem that interferes with the planning and scheduling process. An additional difficulty is the fact that the factory can produce over 3,000 different models of shock absorbers. The production department also changes the plan frequently. This is because the production department wants to achieve a good shift performance plan that is highly rewarded. Another cause of the problem is incorrectly executed detailed plans, in which the times of operations and their order were incorrectly planned. Lack of components on time is another problem resulting from changes in customer orders, but this may also be due to oversights of the purchasing department, which does not control deliveries, does not respond in a timely manner to delays and does not inform the planning department about these issues, the information of which could change the 
production plan. This problem also applies to planning, from components in transit, which makes it difficult to create detailed plans and sometimes causes production stops. Another problem is losing components.

Table 1.

5 Whys analysis

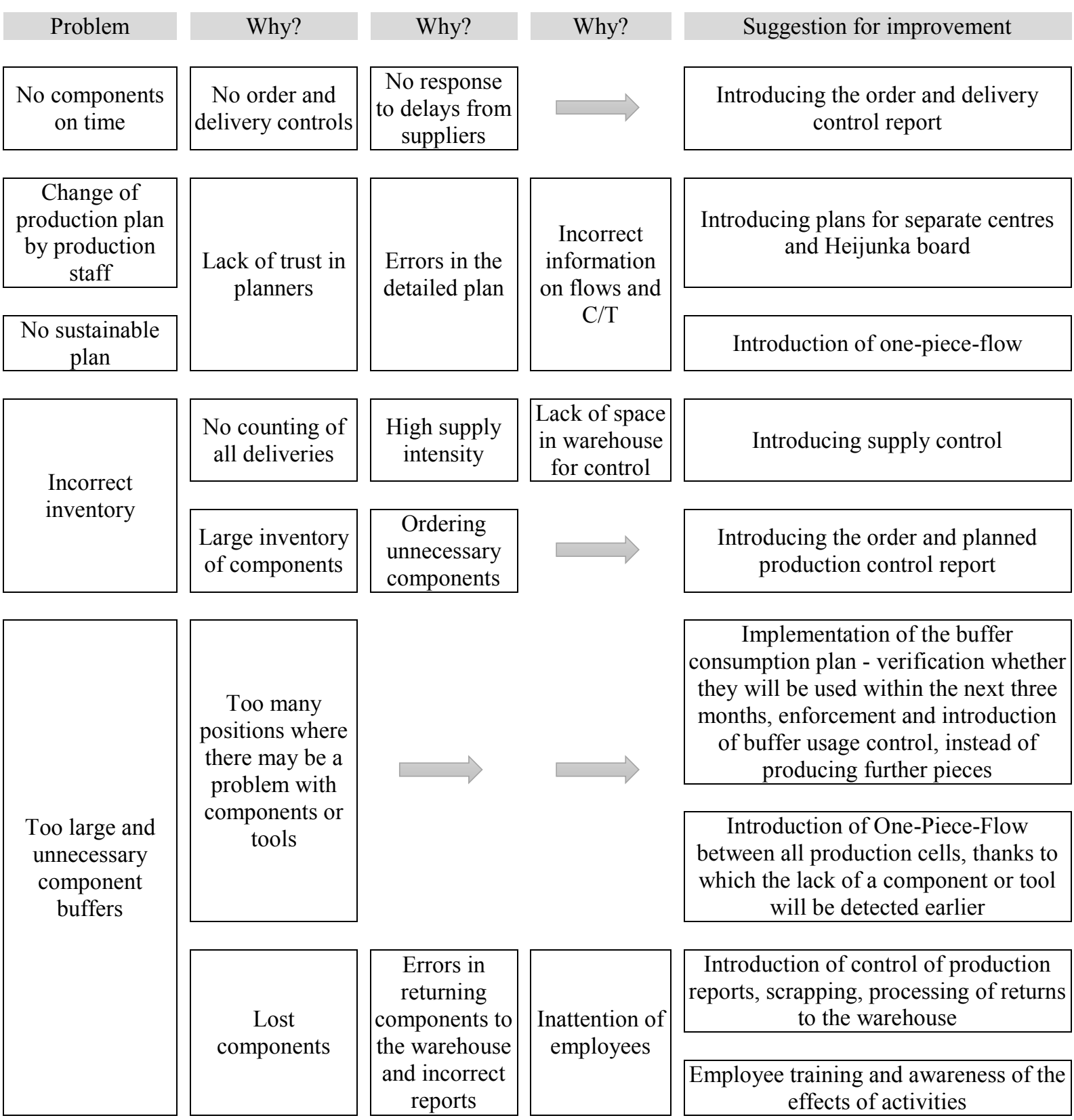

Planners often "see" a large number of components in the system, after which it turns out that they cannot be located in the warehouse. The reasons are incorrectly performed returns from production, incorrectly conducted scrap reports and the issuing of too many components for production. Unplanned buffer states of semi-finished products result from unintentional production breaks caused by a lack of efficient tools and machine failures. Incorrect inventory results from a lack of counting and control of deliveries. The high frequency of deliveries and 
the small number of employees means that the checks are selective and cursory. Thanks to the 5 Whys analysis, one can propose a set of solutions that are designed to eliminate problems. Such solutions are:

- introduction of control reports for planned production, orders and deliveries,

- introduction of plans separately for each machining centre and Heijunka board,

- introduction of the One-Piece-Flow system,

- introduction of supply control,

- implementation of a buffer consumption control plan - verification whether within the next three months they will be used instead of producing more pieces,

- introducing control of production reports, scrapping and returns to the warehouse,

- training employees and making them aware of the effects of their incorrect activities.

On the basis of identified causes and developed improvement proposals, an improvement plan was prepared, which included five steps:

Step 1. Introduction of control reports for: customer orders, deliveries corresponding to orders and production.

Step 2. Implementation of the One-Piece-Flow system, first for the front shock absorber production line and finally for the entire production process.

Step 2. Minimising buffers and limiting components to work in progress by: developing a buffer consumption plan and updating the buffer size in relation to the implemented plan.

Step 4. Periodic update of retooling times and flows for existing assortment and new production models.

Step 5. Implementation of the Heijunka system and Kanban cards for machine retooling, which will facilitate ongoing production planning.

\section{One-Piece-Flow}

The most complicated and deep change is implementation of the One-Piece-Flow method. It allows for the minimisation of the production inventory in progress and production buffers. Thanks to this method, incompatibilities regarding tools, process or lack of components will be detected at the first piece or before production begins, which allows for quick response to errors.

Figure 5 presents the first proposal for changes in the flow of materials through the cells. The stations connected by arrows mean standard flow through them in batches, and those which are not connected by an arrow - One-Piece-Flow. For such connections, the components flow smoothly without the need to create buffers (the original diagram is shown in Fig. 3). 


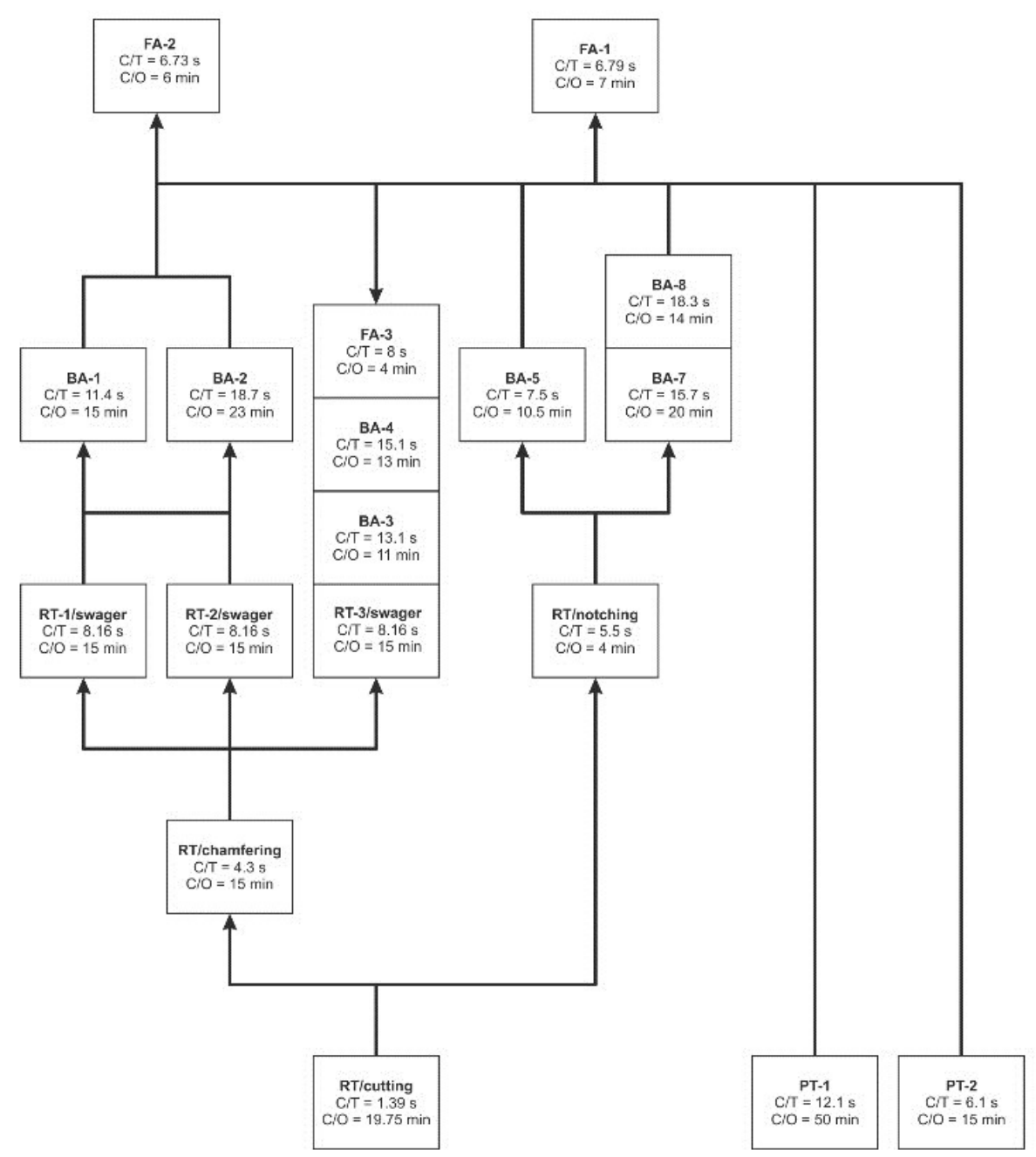

Figure 5. One-Piece-Flow proposal for selected production cells.

The introduction of One-Piece-Flow can increase production capacity. To demonstrate this, one must first calculate the time available for production and the number of items that can be produced for each of the variants. The company works in 3 shifts, 8 hours each, of which 30 minutes for each shift are employee breaks; thus, the time available for production is 22.5 hours a day, i.e. $81,000 \mathrm{sec}$.

The production capacity in the existing machining cell system was calculated for lots of 250 and 550 pieces. The calculations did not include RT operations (cutting and chamfering) and PT-1 and PT-2, because the semi-finished products produced there are also supplied from the supplier, and the production capacity of these positions would falsify results. The data is presented in Table 2.

Knowing the maximum quantity that all production stations are able to produce, with a batch of 250 items (this is the minimum production lot), one can estimate the maximum production volume. On the FA-1 line, a maximum of 7,750 items can be produced during 3 shifts with 31 changeovers (the bottleneck is production on BA-8 and BA-7); on the FA-2 line, it is 8,000 items with 32 changeovers (the same quantity is produced by both FA-2 and on 
the BA-1 and BA-2 - the sum of units produced); on the FA-3 line, it is 4,250 items with 17 changeovers (BA-4 is the bottleneck here), which gives a total of 19,750 items with 76 changeovers. However, such a large number of changeovers is unacceptable.

Table 2.

Calculation of production capacity for lots of 250 and 550 pcs.

\begin{tabular}{|c|c|c|c|c|c|c|c|c|c|c|c|c|}
\hline \multicolumn{7}{|c|}{ Lot of 250 pcs. } & \multicolumn{6}{|c|}{ Lot of 550 pcs. } \\
\hline Station & $5 \bar{\sigma}$ & 仓 & 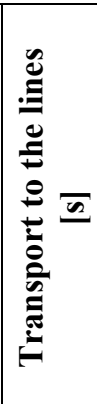 & 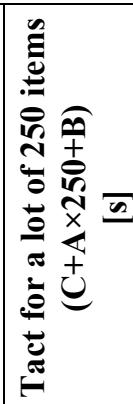 & 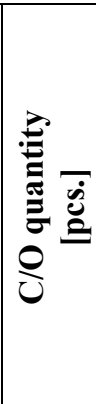 & 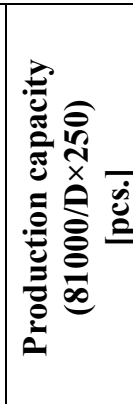 & $\frac{5}{\delta} \bar{a}$ & 记罣 & 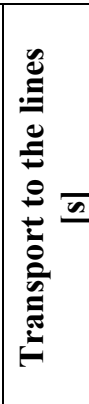 & 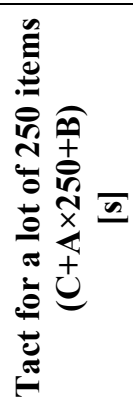 & 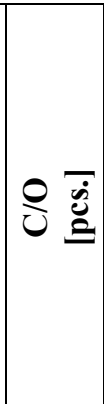 & 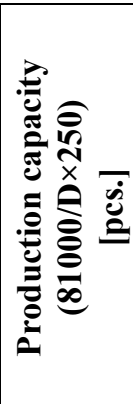 \\
\hline & A & $\mathrm{B}$ & $\mathrm{C}$ & $\mathrm{D}$ & $\mathrm{E}$ & $\mathrm{F}$ & A & $\mathrm{B}$ & $\mathrm{C}$ & $\mathrm{D}$ & $\mathrm{E}$ & $\mathrm{F}$ \\
\hline $\begin{array}{l}\text { RT swag. } \\
\text { (3 machines) }\end{array}$ & 8,16 & 15 & 60 & 3000 & 27 & 6750 & 8,16 & 15 & 60 & 5448 & 14 & 7700 \\
\hline RT notch. & 5.5 & 4 & 90 & 1705 & 47 & 11750 & 5.5 & 4 & 90 & 3355 & 24 & 13200 \\
\hline BA-1 & \begin{tabular}{|l|}
11.4 \\
\end{tabular} & 15 & 300 & 4050 & 20 & 5000 & \begin{tabular}{|l|}
11.4 \\
\end{tabular} & 15 & 300 & 7470 & 10 & 5500 \\
\hline BA-2 & \begin{tabular}{|l|}
18.7 \\
\end{tabular} & 23 & 300 & 6355 & 12 & 3000 & \begin{tabular}{|l|}
18.7 \\
\end{tabular} & 23 & 300 & 11965 & 6 & 3300 \\
\hline BA-3 & \begin{tabular}{|l|}
13.1 \\
\end{tabular} & 11 & 300 & 4235 & 19 & 4750 & 13.1 & 11 & 300 & 8495 & 9 & 4950 \\
\hline BA-4 & \begin{tabular}{|l|}
15.1 \\
\end{tabular} & 17,5 & 60 & 4615 & 17 & 4250 & \begin{tabular}{|l|}
15.1 \\
\end{tabular} & 13 & 60 & 9415 & 8 & 4400 \\
\hline BA-5 & 7.5 & 10,5 & 300 & 2805 & 28 & 7000 & 7.5 & 10,5 & 300 & 5055 & 16 & 8800 \\
\hline BA-7 & \begin{tabular}{|l|}
15.7 \\
\end{tabular} & 20 & 300 & 5425 & 14 & 3500 & 15.7 & 20 & 300 & 10135 & 7 & 3850 \\
\hline BA-8 & \begin{tabular}{|l|}
18.3 \\
\end{tabular} & 14 & 60 & 5475 & 14 & 3500 & \begin{tabular}{|l|}
18.3 \\
\end{tabular} & 14 & 60 & 10965 & 7 & 3850 \\
\hline FA-1 & \begin{tabular}{|l|}
6.79 \\
\end{tabular} & 7 & 480 & 2597.5 & 31 & 7750 & \begin{tabular}{|l|}
6.79 \\
\end{tabular} & 7 & 480 & 4634.5 & 17 & 9350 \\
\hline FA-2 & 6.73 & 6 & 480 & 2522.5 & 32 & 8000 & 6.73 & 6 & 480 & 4541.5 & 17 & 9350 \\
\hline FA-3 & 8 & 4 & 480 & 2720 & 29 & 7250 & 8 & 4 & 480 & 5120 & 15 & 8250 \\
\hline
\end{tabular}

The number of changeovers that has been calculated for a batch size of 550 pieces is 41 , and the quantity produced is 22,550 pieces, of which the production of rear shock absorbers is 9,350 pieces, and the front-13,200 pieces. Process indicators after making changes for the flow of one piece of selected production cells (production lines for frontshock absorbers) are shown in Table 3.

Table 3.

Calculations of production capacity after the introduction of One-Piece-Flow

\begin{tabular}{|c|c|c|c|c|c|c|}
\hline Station & $\begin{array}{c}\mathbf{C} / \mathbf{T} \\
{[\mathbf{s}]}\end{array}$ & $\begin{array}{c}\mathrm{C} / \mathrm{O} \\
{[\mathrm{min}]}\end{array}$ & $\begin{array}{c}\text { Transport } \\
\text { to lines } \\
{[\mathbf{s}]}\end{array}$ & $\begin{array}{c}\text { Tact for a lot } \\
\text { of } 250 \text { items } \\
(\mathrm{C}+\mathrm{A} \times \mathbf{2 5 0 + B}) \\
{[\mathrm{s}]}\end{array}$ & $\begin{array}{c}\mathrm{C} / \mathrm{O} \\
{[\text { pes.] }}\end{array}$ & $\begin{array}{c}\text { Production } \\
\text { capacity } \\
(81000 / D \times 250) \\
{[\text { pcs. }]}\end{array}$ \\
\hline & A & $\mathrm{B}$ & $\mathrm{C}$ & $\mathrm{D}$ & $\mathrm{E}$ & $\mathrm{F}$ \\
\hline RT swag. + BA-3 + BA-4 + FA-3 & 44.36 & 13 & 60 & 9166.26 & 8 & 4400 \\
\hline RT swag. + BA-1 & 19.56 & 15 & 60 & 7238,16 & 11 & 6050 \\
\hline RT swag. + BA-2 & 26.86 & 23 & 60 & 11733.16 & 6 & 3300 \\
\hline FA-2 & 6.73 & 6 & 480 & 4541.5 & 17 & 9350 \\
\hline
\end{tabular}


After the introduction of changes, the volume of daily production increased by 550 items, reorganising only RT swager stations, along with BA-1 and BA-2. Changes after introducing connections for RT swager and BA-3, BA-4 and FA-3 did not bring the expected results, because the times of production and changeovers at these positions are too diverse. The analysis allowed for the rejection of the variant, which assumed the purchase of an additional FA station, which was intended to introduce the flow of one piece for RT swager + BA-1 and RT swager + BA-2. The FA-2 station has sufficient production capacity to meet BA-1 and BA-2 capacity. When analysing the production capacity of FA-3 stations together with BA-3 and BA-4, it can be seen that the FA-3 capacity is not sufficiently used, so additional BA-3 'and BA-4' stations can be added, which will double the capacity of this line. The second way is to increase production batches only for those stations where it will increase productivity.

In order to improve performance for the RT-swager + BA-3 + BA-4 + FA-3 workstation lines, calculations were carried out to select the optimal production batch size, as shown in Table 4.

Table 4.

Selection of optimal production batch size

\begin{tabular}{|c|c|c|c|c|c|c|}
\hline $\begin{array}{l}\text { Lot } \\
\text { [pes.] }\end{array}$ & $\begin{array}{c}\mathbf{C} / \mathbf{T} \\
{[\mathbf{s}]}\end{array}$ & $\begin{array}{c}\mathrm{C} / \mathrm{O} \\
{[\mathrm{min}]}\end{array}$ & $\begin{array}{c}\text { Transport to } \\
\text { lines } \\
{[\mathbf{s}]}\end{array}$ & $\begin{array}{c}\text { Tact for a lot } \\
\text { of } 250 \text { items } \\
(\mathbf{C}+\mathbf{A} \times 250+B) \\
{[\mathbf{s}]}\end{array}$ & $\begin{array}{c}\mathrm{C} / \mathrm{O} \\
\text { [pes.] }\end{array}$ & $\begin{array}{c}\text { Production } \\
\text { capacity } \\
(81000 / D \times 250) \\
{[\text { pcs.] }}\end{array}$ \\
\hline & $\bar{A}$ & B & $\bar{C}$ & $\mathrm{D}$ & $E$ & $F$ \\
\hline 250 & 44.36 & 13 & 60 & 4644 & 17 & 4250 \\
\hline 500 & 44.36 & 13 & 60 & 8419 & 9 & 4500 \\
\hline 550 & 44.36 & 13 & 60 & 9166 & 8 & 4400 \\
\hline 600 & 44.36 & 13 & 60 & 9929 & 8 & 4800 \\
\hline 825 & 44.36 & 13 & 60 & 13327 & 6 & 4950 \\
\hline 1100 & 44.36 & 13 & 60 & 17479 & 4 & 4400 \\
\hline
\end{tabular}

The company achieves the largest production result by producing batches of 825 items, but such a large production batch would cause an excessive increase in the stock of finished products, because the company produces a very diverse range (over 3,000 models). Production in batches of 500 pieces (twice the size of the minimum batch) was considered to be satisfactory.

The introduction of the One-Piece-Flow system for the entire production process would involve the expansion of the process by additional FA-4 and FA-5 stations that would support the front and rear shock absorber lines. This solution was rejected in the initial analysis process due to unacceptable investment costs.

\section{Discussion of results}

After introducing all five foreseen elements of the process improvement plan in the enterprise, the expected state map was developed, which is presented in Figure 6. 


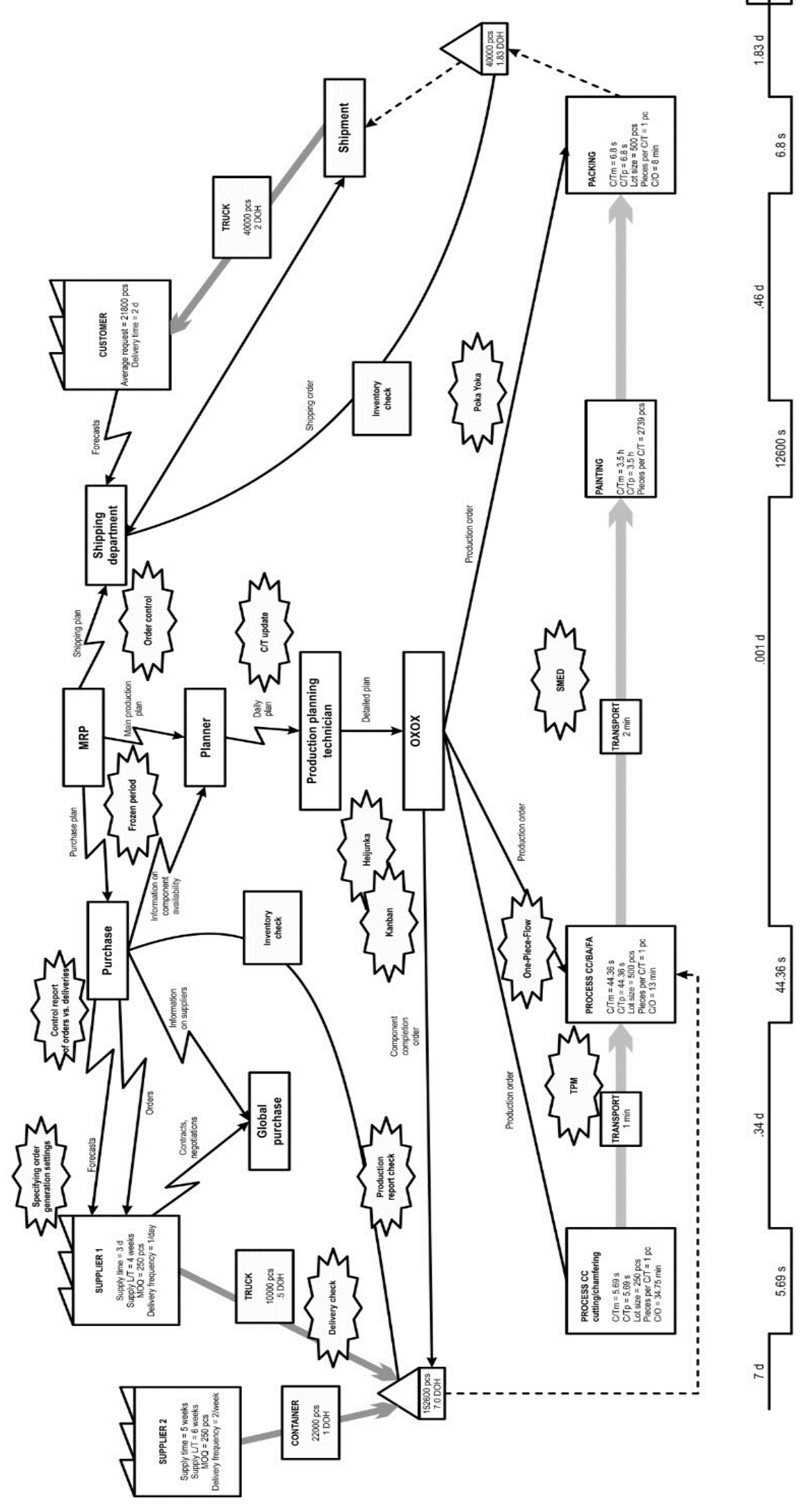

Figure 6. Expected state map. 
The first step concerned the introduction of reports that would help avoid entering incorrect data into the system and control over production reports, thanks to which the production planning department will be based on data with greater correctness. Such actions will prevent the creation of production buffers and stopping production caused by a lack of components.

The second step of the improvement plan was the introduction of One-Piece-Flow, which was to increase production efficiency, reduce production buffers and streamline planning. Production efficiency was not increased as expected and was increased by 550 pcs per day. The reason for this is very diverse cycle times and changeover times at subsequent production stations. In order for One-Piece-Flow to bring greater benefits in the form of better production results, SMED (Single Minute Exchange of Die) and TPM systems should be introduced to balance cycle and changeover times. One-Piece-Flow stopped unnecessary production that built production buffers between successive production cells. Production preparation is carried out consistently and not separately, which permits reacting to non-compliance on the production of one piece and not after the whole batch is produced at the previous workstation.

The third step is tightly connected to the second and consists in minimising buffers. The second step prevents their re-emergence, and the third step is determines the action plan of using non-rotating stock to aim for buffers between cells in a size of 7,500 pcs.

The fourth step is to update $\mathrm{C} / \mathrm{T}$ and production flows, which will facilitate production planning so that plans will be created in a way that maximises the efficiency of the production system.

The fifth step is to introduce a new planning procedure that involves balancing production and planning based on product families.

The introduction of the improvement plan allowed for the minimisation of inventory from 138,062 units to 25,000 units, which reduced costs, waste and L/T from 56.96 days to 9.67 days. Production lead time remained unchanged, however, and the FA-3 station efficiency (the Heijunka planning system was introduced here) was increased from $22.5 \mathrm{~h}$ to $19.5 \mathrm{~h}$ for 4,250 products.

The next step which should be implemented in the future and would increase the efficiency of the One-Piece-Flow cells is SMED and TPM. Thanks to the unification of changeover times and cycle times, the production process would be more stable and would not create an in-process inventory of work in progress. 


\section{Conclusion}

Based on the research of analyses, implementations and verifications carried out, the following conclusions were formulated:

1. Value Stream Mapping analysis allowed for the identification and synthetic recognition of:

- main client requirements: daily needs and frequency of delivery,

- stages of the production process, cycle times, changeover times, transport times and storage volumes of semi-finished products between cells,

- terms of cooperation with suppliers: minimum number of orders, transport times, lead time of suppliers, frequency of deliveries,

- planning system,

- client-enterprise and enterprise-supplier communication system.

2. Value Stream Mapping analysis detected the main errors occurring in the enterprise, which are:

- lack of components on time,

- losing components,

- large inventory,

- unnecessary and too large buffers,

- plan changes introduced by production employees,

- incorrect inventory,

- incorrect information about $\mathrm{C} / \mathrm{T}$ and flows through subsequent workstations,

- no sustainable plan,

- frequent changes of orders by the customer,

- large plan changes during update.

3. The 5 Whys analysis showed links between problems, and some of them have a common source of occurrence, such as:

- change of production plan by production staff,

- frequent changes in customer orders that generate unnecessary demands,

- a large number of workstations that generate unnecessary buffers,

- incorrect information about $\mathrm{C} / \mathrm{T}$, which is the cause of erroneous production plans.

4. The 5 Whys analysis helped identify solutions:

- preparing additional reports in the warehouse, production and planning,

- introducing sustainable production planning and control using Heijunka boards and Kanban cards,

- creating daily plans based on what was originally planned in the frozen period (MPS), 
- introduction of the One-Piece-Flow system,

- introduction of TPM and SMED systems.

5. The introduction of changes allowed for:

- reduction of production buffers from 138,062 items to 25,000 items, which in turn reduced $\mathrm{L} / \mathrm{T}$ from 56.96 days to 9.67 days,

- increasing production efficiency, from $22.5 \mathrm{~h}$ to $19.5 \mathrm{~h}$ for 4,250 pieces of products,

- balancing production and planning and eliminating errors in production plans.

\section{Acknowledgements}

This article was prepared within the statutory research work number 3/010/BK_19/0034 performed within Silesia University of Technology, Faculty of Organization and Management, Institute of Economics and Informatics.

\section{References}

1. Alonso, M., and Comas, Á. (2006). Modelling a Twin Tube Cavitating Shock Absorber. Proceedings of the Institution of Mechanical Engineers, Part D: Journal of Automobile Engineering, 220(8), 1031-1040. https://doi.org/10.1243/09544070D23104.

2. Antosz, K., Pacana, A., Stadnicka, D. and Zielecki, W. (2013). Narzędzia Lean Manufactruring. Rzeszów: Oficyna Wydawnicza Politechniki Rzeszowskiej.

3. Charczyńska S. (2018). Analiza $i$ doskonalenie systemu planowania, sterowania $i$ harmonogramowania produkcji na przykładzie wybranego przedsiębiorstwa branży automotive. Silesian University of Technology, Faculty of Organization and Management, Zabrze.

4. Cholewicka-Goździk, K. (2001). Metoda LEAN - doskonalenie procesów i produktów. Problemy Jakości, 1, 21-25.

5. Czerska, J. (2012). Pozwól płynąc swojemu produktowi. Tworzenie ciagłego przepływu. Warszawa: Placet.

6. Czerska, J. (2014). Doskonalenie strumienia wartości. Gdańsk: LeanQ Team.

7. Dyczkowska, J. (2012). Logistyka zaopatrzenia i produkcji - wpływ na logistykę dystrybucji. Prace Naukowe Politechniki Warszawskiej, s. Transport, 84, 19-28.

8. Fertsch, M., Cyplik, P. and Hadaś, Ł. (2010). Logistyka produkcji. Teoria i praktyka. Poznań: Instytut Logistyki i Magazynowania. 
9. Fujimoto, T. (1999). The evolution of a manufacturing system at Toyota. New York: Oxford University Press.

10. Gulati, R. (2009). Maintenance and reliability best practices. New York: Industrial Press.

11. Hąbek, P. (2013). Koncepcja zrównoważonego wytwarzania i jej praktyczna realizacja na przykładzie przedsiębiorstwa przemysłu motoryzacyjnego. In: W. Biały, M. Zasadzień (Eds.), Systemy wspomagania $w$ inżynierii produkcji (pp. 77-86). Wspomaganie zarzadzania systemami produkcyjnymi. Gliwice: P.A. NOVA.

12. Hirano, H., and Shimbun, N.K. (1989). Poka-yoke: improving product quality by preventing defects. New York: Productivity Press.

13. Hobbs, H. (2003). Lean Manufacturing Implementation. Plantation: J. Ross Publishing.

14. Jóźwiakowski, P. (2015). Lean management-metoda racjonalnego zarządzania produkcją. Zeszyty Naukowe Dolnośląskiej Wyższej Szkoły Przedsiębiorczości i Techniki. Studia z Nauk Technicznych, 4, 33-46.

15. Klimecka-Tatar, D. (2017). Value Stream Mapping as Lean Production tool to improve the production process organization - case study in packaging manufacturing. Production Engineering Archives, 17, 41-45.

16. Kolasiński, S., and Wiśniewski, Z. (2016). Rekonfiguracja systemu wytwórczego z pomocą mapowania strumienia wartości - studium przypadku. Zeszyty Naukowe Politechniki Śląskiej, s. Organizacja i Zarzadzanie, 99, 585-597.

17. Kruczek, M., and Żebrucki, Z. (2012). Wykorzystanie techniki SMED w usprawnieniu procesu produkcyjnego. Logistyka, 2, 779-806.

18. Lean Enterprise Institute (LEI). (2003). Lean lexikon: a graphical glossary for Lean Thinkers. Massachusetts: Lean Enterprise Institute Inc.

19. Legutko, S. (2009). Trendy rozwoju utrzymania ruchu urządzeń i maszyn. Eksploatacja i Niezawodność, 2(42), 8-16.

20. Locher, D.A. (2008). Value Stream Mapping for Lean Development. New York: Productivity Press.

21. Łazicki, A. (2011). System zarzadzania przedsiębiorstwem. Techniki Lean Management i Kaizen. Warszawa: Wiedza i Praktyka.

22. Małkus, T., and Onderka, Z. (2015). Projektowanie systemów logistycznych i operacyjnych. In: A. Stabryła (Ed.), Metodologia projektowania systemów organizacyjnych przedsiębiorstwa. Warszawa: C.H. Beck.

23. Masaaki, I. (2007). Kaizen - Klucz do konkurencyjnego sukcesu Japonii. Kraków: MT Biznes.

24. Matuszek, J. (2012). Logistyka produkcji. Wałbrzych: Wydawnictwo Uczelniane PWSZ im. Angelusa Silesiusa.

25. Michlowicz, E. (2011). Nowe zadania logistyki produkcji. Logistyka, 2, 465-476.

26. Michlowicz, E. (2012). Planowanie poprawy ciągłości przepływu materiałów w firmie produkcyjnej. Logistyka 2, 915-923. 
27. Muniyappa, M., and Shiva, P. H. C. (2014). Value Stream Mapping: A Lean Tool. The International Journal of Busniess Management, 2, 100-104.

28. Nash, M.A., and Poling, S.R. (2008). Mapping the Total Value Stream: A Comprehensive Guide for Production and Transactional Processes. New York: Productivity Press.

29. Odlanicka-Poczobutt, M. and Kulińska, E. (2014). Usprawnienia w obszarze logistyki produkcji w przedsiębiorstwach branży krawieckiej. Logistyka, 4, 2291-2300.

30. Ordysiński, T. (2013). Kanban based information management in organization. Studia i Materiaty Polskiego Stowarzyszenia Zarzadzania Wiedza, 63, 76-85.

31. Pająk, E. (2006). Zarzadzanie produkcja. Warszawa: PWN.

32. Pascal, D., and Shook, J. (2007). Lean Production Simplified: A Plain Language Guide to the World's Most Powerful Production System. New York: Productivity Press.

33. Pawłowski, E., Pawłowski, K., and Trzcielski, S. (2010). Metody i narzędzia Lean manufacturing. Poznań: Wydawnictwo Politechniki Poznańskiej.

34. Picchi, F.A. \& Granja, A.D. (2004.08.3-5). Construction Sites: Using Lean Principles to Seek Broader Implementations. 12th Annual Conference of the International Group for Lean Construction. Helsingør, Denmark.

35. Rother, M., Shook, J. (2003). Learning to see: value stream mapping to add value and eliminate Muda. Massachusetts: Lean Enterprise Institute.

36. Stanek, K., Czech, P., and Barcik, J. (2011). Metodologia World Class Manufacturing (WCM) w fabryce Fiat Auto Poland S.A. Zeszyty Naukowe Politechniki Śląskiej, s. Transport, 71, 65-72.

37. Szwedzka, K., Lubiński, P. and Jasiulewicz-Kaczmarek, M. (2014). Redukcja czasu przezbrojeń metodą SMED: studium przypadku, Logistyka, 6, 14816-14825.

38. Szymańska-Brałkowska, M. (2010). Kaizen - metoda zwiększenia produktywności przedsiębiorstwa. In: T. Sikora (Ed.), Zarzadzanie jakoscia - doskonalenie organizacji, 1, 603-613.

39. Szymonik, A. (2011). Logistyka i zarzadzanie tańcuchem dostaw, część 2. Warszawa: Diffin.

40. Szymonik, A. (2012). Logistyka produkcji Procesy Systemy Organizacja. Warszawa: Difin.

41. Tommelein, I., and Weissenberger, M. (1999). More just-in-time: location of buffers in structural steel supply and construction processes. Annual Conference of the International Group for Lean Construction, Berkeley: University of California, 7, 109-120.

42. Topolski, M., Topolska, K., and Kobyłt, A. (2015). Sterowanie przepływem materiałów w procesie produkcyjnym. Logistyka, 2, 765-772.

43. Trojanowska, J., Kolińska, K., and Koliński, A. (2011). Stosowanie narzędzi Lean w przedsiębiorstwach produkcyjnych jako skuteczny sposób walki z kryzysem gospodarczym. Problemy Zarzadzania, 1(31), 34-52. 
44. Wolniak, R. (2013). Metody i narzędzia Lean Production i ich rola w kształtowaniu innowacji w przemyśle In: R. Knosala (Ed.), Innowacje $w$ zarzadzaniu $i$ inżynierii produkcji. Opole: Oficyna Wydawnicza Polskiego Towarzystwa Zarządzania Produkcją, 524-534.

45. Womack, J.P., Jones, D.T. (1996). Lean thinking: banish waste and create wealth in your corporation. New York: Simon and Schuster.

46. Womack, J.P., Womack, J.P., Jones, D.T., Roos, D. (1990). Machine that changed the world. New York: Simon and Schuster. 